\title{
A review on the phytochemical and pharmacological properties of Hyptis suaveolens (L.) Poit
}

\author{
Pratibha Mishra, Saima Sohrab and Sanjay Kumar Mishra* ${ }^{*}$
}

\begin{abstract}
Background: Plants are the repository of variable number of valuable secondary metabolites that bears pharmacognostic and pharmacological implications having potentiality to emerge as super drugs in future. In-vivo production of these metabolites is influenced by the biotic and abiotic stresses resulting in continuous accumulation of diverse phytochemicals and their derivatives that can be useful in designing and developing potential drugs for future. The aim of the present study is to review the existence of medicinally important secondary metabolites and possible pharmacological and pharmacognostic importance of under-explored weed plant species Hyptis suaveolens (L.) Poit., to explore the potentiality of the plant for developing and designing the drugs for future.

Main body of the abstract: Hyptis suaveolens belonging to family Lamiaceae is the rich source of medicinally important phytochemicals like essential oils, tannins, saponins, phenols, flavonoids, terpenoids, alkaloids, and sterols. One or many of these compounds have antioxidative, anti-inflammatory, antispasmodic, anti-septic, anti-cancer, anti-ulcer, antimicrobial, antibacterial, antiviral, antifungal, anti-diabetic, anti-fertility, diaphoretics, anticutaneous, anticatarrhal, antirheumatic, anti-ulcer, gastroprotective, immunomodulatory, analgesic, and antiviral activity.
\end{abstract}

Short conclusion: Hyptis suaveolens contains unique terpenoid metabolites like suaveolic acid, suaveolol, methyl suaveolate, beta-sitosterol, ursolic acid, and phenolic compound like rosamarinic acid, methyl rosamarinate that have potentiality to substitute the traditional drugs as therapeutic agent against the resistant and newly emerged bacterial and viral pathogens. Pentacyclic triterpenoid, ursolic acid have been reported to have effective antiviral response against the SARS-CoV2 responsible for the present COVID-19 pandemic and HIV virus for which no effective vaccines are available till date. Ursolic acid has the ability to modulate the activity of main protease ( $\mathrm{M}^{\mathrm{pro}}$ ) that is essential for processing of SARS-CoV2 replicasetranscriptase machinery needed for viral replication and particle assembly.

Keywords: Lamiaceae, Pharmacological, Triterpenoids, Suaveolic acid, Ursolic acid, Main protease

\section{Background}

The history of pharmacognostic and pharmacological implications of plants is intimately connected with the history of human civilization. A considerable number of plant-based drugs used today in modern system of medicine were used as crude drug source to cure human ailments by the ancient people as evident in ancient literature. Nature has established the parallel store house

\footnotetext{
*Correspondence: sanjaiy1975@gmail.com

Department of Botany, Ewing Christian College, Prayagraj, Uttar Pradesh 211003, India
}

\section{Springer Open}

of plants as herbal remedies to cure human ailments. The modern pharmacopoeia provides the authentic information regarding the plant-based drugs, drug yielding plants, and their pharmacological effects on human body. The pharmacognostic value of plants is due to the presence of immense number of chemically variable secondary metabolites in plants. These pharmacologically active metabolites are produced in different plant parts at different stages of life cycle [1]. They provide additional advantages of promoting effective pollination and

(c) The Author(s). 2021 Open Access This article is licensed under a Creative Commons Attribution 4.0 International License, which permits use, sharing, adaptation, distribution and reproduction in any medium or format, as long as you give appropriate credit to the original author(s) and the source, provide a link to the Creative Commons licence, and indicate if changes were made. The images or other third party material in this article are included in the article's Creative Commons licence, unless indicated otherwise in a credit line to the material. If material is not included in the article's Creative Commons licence and your intended use is not permitted by statutory regulation or exceeds the permitted use, you will need to obtain permission directly from the copyright holder. To view a copy of this licence, visit http://creativecommons.org/licenses/by/4.0/. 
dispersal of seeds and other propagules or to protect the plants from the biotic and abiotic stresses [2].

The ever-changing climatic conditions not only affect the life cycle pattern, distribution, phenological, and phytosociological behavior of the plants but it also imposes noticeable stress on genomic organization and consequent change in the phytochemical profile of individual plant species growing under diverse conditions of environmental stresses. The imposed environmental stress affects the gene expression pattern and results in accumulation of diverse categories of secondary metabolites and its derivatives, changing the chemical profile within the individuals of a species growing under diverse ecological niches. These diverse secondary metabolites produced by the plants have ability to produce specific pharmacological responses making particular plant species a potential source of new medicine. The Indian subcontinent exhibits diverse climatic conditions due to prevailing geographical diversity which in turn largely controlled by annual monsoon, appears to be experiencing increasingly severe and erratic precipitation and resultant inter-specific and intra-specific diversity in the plant populations growing under different ecological habitats. Therefore, there is a need to analyze the characteristic chemical profile of the medicinally important plants growing under diverse climatic conditions and to understand how variation in temperature, moisture, and edaphic factors might affect the quality and quantity of pharmacologically valuable secondary metabolites. Some important phytochemicals found in plants are phenolics, alkaloids, terpenoids, glycosides, tannins, flavonoids, saponins, steroids, carbohydrates derivatives, gums, essentials oils, fatty oils, resins, mucilages, etc., that bear diverse pharmacological and pharmacognostic implications [3].

Hyptis suaveolens (L.) Poit. is one of the underexplored valuable medicinal plant used to treat various ailments in traditional system of medicine. It is an obnoxious weed of tropics and subtropics. The leaves of the plant are the source of pharmacologically important secondary metabolites having antispasmodic, anti-colic, anti-rheumatic, and anti-fertility properties [4]. The pharmacological significance of $H$. suaveolens is due to its sedative, diuretic, antispasmodic, aromatic, anti-inflammatory, anti-catarrhal, anti-cutaneous, anti-pyretic, ant-rheumatic, anti-soporific, and anti-cancer properties [5]. The essential oils contained in the leaves have potential antimicrobial and antifungal properties [6-8]. The root extract contains anti-retroviral compound called urosolic acid, a triterpenoid that may target retroviral integrases and proteases blocking the replication of retroviruses such as HIV $[9,10]$. Most of these bioactive compounds found in $H$. suaveolens are used as therapeutic agent or as the precursors of useful drugs [11]. The mature leaves of $H$. suaveolens contain alkaloids as the major secondary metabolite followed by tannins and saponins respectively [12].

Family Lamiaceae or Labiatae popularly known as Mint family contains 236 genera and 6900-7000 species of aromatic plants [13]. Members of this family are herbs (perennial or annual herbs), shrubs, and trees. Stems are herbaceous rarely woody, prostrate and branched. Leaves are simple and oppositely arranged, rarely whorled, petiolate or sessile, hairy with characteristic aroma due to presence aromatic essential oils.

\section{Main text}

Taxonomic status of Hyptis suaveolens (L.) Poit.

Hyptis is one of the largest genus with more than 300 species of herbs, shrubs, and small trees, which belongs to the sub-family Nepetoideae under family Lamiaceae [14]. H. suaveolens (L.) Poit. is an annual or perennial herb exhibiting characteristic genotypic polymorphism and plasticity in morphological and physiological attributes [15]. It can grow luxuriantly in diverse environmental conditions due to the presence of variety of chemical compounds that provide it adaptive and survival advantages [16].

\section{Morpho-taxonomical features of Hyptis suaveolens (L.) Poit.}

H. suaveolens (L.) Poit., popularly known as vilayati tulsi, bush mint, bush tea in India, is suffrutescent annual or perennial herbaceous weed growing along road sides. The stem is quadrangular, velvety, thick, and covered with long hairs and small erect glandular dots. Leaves are simple, opposite, decussate, and petiolate. The petioles are 2-4-cm-long bearing 2-10-cm-long and 4-6$\mathrm{cm}$-wide leaf blades having irregular serrated margin, covered with glandular hairs. Inflorescence is constituted of panicles or short umbels with 2-5 zygomorphic, blue purplish flowers arising in clusters at axillary positions. The campanulate, 5 teethed calyx ranges from 4 to 6 $\mathrm{mm}$ in length having glandular and pubescent surface marked by 10 ribs. The characteristic two-lipped corolla are blue in color exceeding the length of calyx tube, 8$10 \mathrm{~mm}$ long, lower lips are divided into 3 lobes, 4 didynamous stamens are inserted at the top of corolla tube, ovary divided into 4 lobes, and stylar end is filliform bearing small bilobed stigma at the top of the carpel [17] (Fig. 1).

\section{Phytochemical profile of Hyptis suaveolens (L.) Poit.}

$H$. suaveolens is an aromatic medicinal herb characterized by the presence of diversity of phytochemicals like essential oils, phenolics, di and triterpenoids, steroids, flavonoids, etc. that constitute the chemical profile of the plants. $H$. suaveolens contain high amount of 


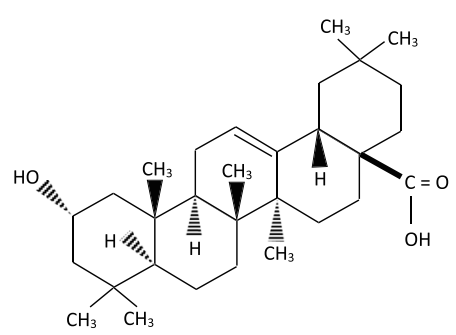

Ursolic Acid

$\left(\mathrm{C}_{30} \mathrm{H}_{48} \mathrm{O}_{3}\right)$

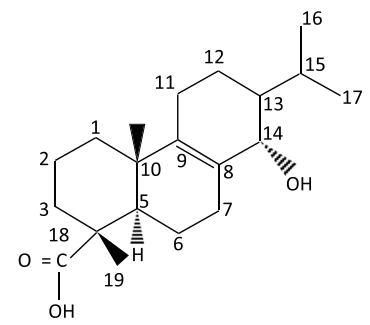

Suaveolic Acid

$\left(\mathrm{C}_{20} \mathrm{H}_{34} \mathrm{O}_{3}\right)$

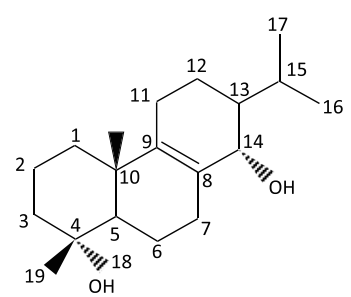

Suaveolol

$\left(\mathrm{C}_{20} \mathrm{H}_{34} \mathrm{O}_{2}\right)$

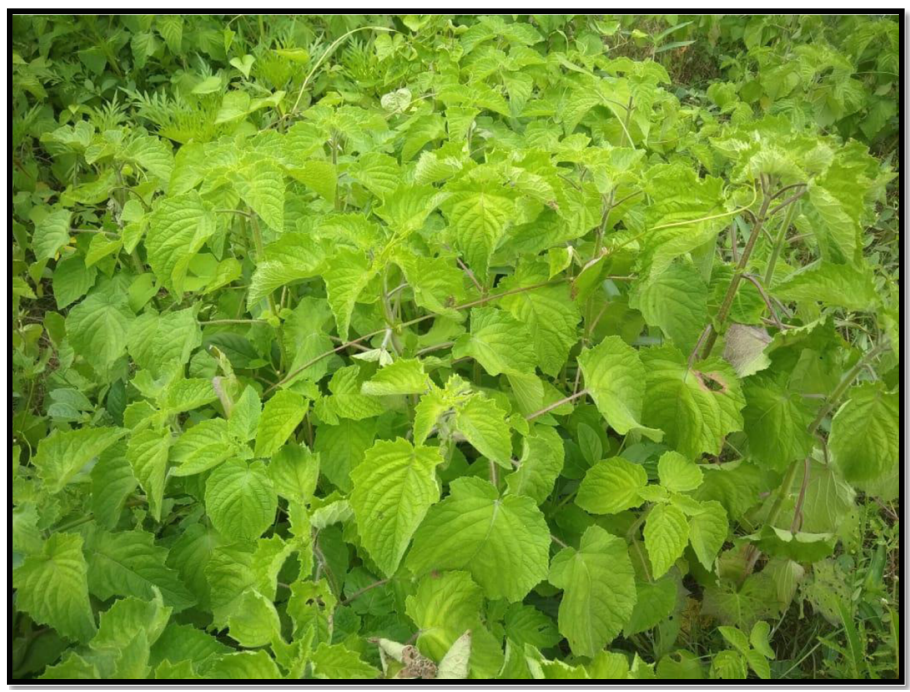

Fig. 1 Hyptis suaveolens (L) 
essential oils in oil glands, followed by alkaloids, flavonoids, tannins, phenolics, and saponins [11].

\section{Phenolic compounds}

Phenolics are the most abundant secondary metabolites synthesized by plants under biotic and abiotic stresses to adapt and survive it in the changing environmental conditions [18]. The phenolics are hydroxyl derivatives of ringed aromatic compounds produced by the plants under stress conditions and they may be categorized as phenolic acids if single ring is present and polyphenolics when more than one aromatic ring is present. The hydroxyl side chain present on the aromatic ring is responsible for the specific biochemical activity of phenolic compounds produced by the plants. Majority of plant phenolics occur as glycosides produced as a result of linkage of different phenolic rings with the sugar or acetylated sugar molecules [19, 20]. Depending upon the structure of aglycones, plant phenolics can be categorized as phenolic acid, flavonoids, polyphenolic amides, and other non-flavonoid polyphenols and their molecular mass ranges between 500 and $4000 \mathrm{Da}$ [21]. The plant phenolics occur in both free and bounded form, the bounded phenolics constitute beta-glycosides through stomach and small intestine, and it reaches the colon in unaltered form where they exert their chemical bioactivity. The phenolic compounds are the potent antioxidants having the ability of scavenging free oxide radicals. The number and position of hydroxyl group and nature of substitution of aromatic rings confer the magnitude of antioxidative potential to the phenolics $[18,22]$. Phenolics exhibits antioxidative property due to its redox potentiality, acting as reducing agent, free radical scavenger, hydrogen donors, metal chelator, quencher of lipid peroxidation, prevent DNA damage from oxidation, and scavenge reactive oxygen species, thus protecting the human body from free radicals [22].

Aromatic family Lamiaceae is characterized by the presence of diverse polyphenolic compounds like proanthocyanidins, prodelphinidins, profisetinidins, rosamarinic acid and methyl rosamarinate, caffeic acid, gentisic acid, p-hydroxybenzoic acid, vanillic acid, syringic acid, p-coumaric acid, protocatechuic acid, ferulic acid, chicoric, and caftaric acids in high concentration [23]. The leaves of $H$. suaveolens contain free polyphenols more abundantly than bound polyphenols, having higher antioxidant properties that are responsible for their protective effect from oxidative stresses by scavenging reactive oxygen species (ROS). Polyphenolics present in $H$. suaveolens have well established strong and effective antioxidative, hepatoprotective, cytoprotective, neuroprotective, and antimicrobial activity [24-27]. The $\mathrm{Fe}^{++}$ chelating ability of polyphenols protects human brain from iron induced lipid peroxidation [28].

\section{Flavonoids}

Flavonoids are the complex group of naturally occurring phenolics in plants, characterized by universal presence of phenyl-benzo-pyrone ring system. The flavonoids occur in free state or as glycosides (O-glycosides or Cglycosides) with its diverse derivatives like flavones, flavonol, flavanone, isoflavone, and chalcone anthocyanidins [29]. The flavonoids are present in glycosylated or esterified form, and are synthesized from derivatives of amino acid phenylalanine and acetic acid through shikimic acid pathway [29]. In plants, about 2000 types of flavonoids have been reported having antibacterial, antimicrobial, anti-cancer, anti-inflammatory, anti-diabetic, anti-aging, antiviral, cardioprotective activity, hence flavonoids are considered to be an important bioactive chemical constituent of pharmacologically reputed medicinal plants. It exhibits its anti-cancer activity by promoting apoptosis, induction of cell cycle arrest, proteasome inhibition, and by adversely interacting with carcinogenic enzymes [30]. Flavonoids acts as natural anti-inflammatory compounds by acting as potent inhibitor of transcription factors that modulate the expression of gene that produces inflammation inducer like cytokines, chemokines, and eicosanoids that results in inflammatory response by enhancing beta cell function of queretin-3-glucoside in diseases like, cardiovascular impairment, rheumatoid arthritis, leukemia, ileitis, sepsis, psoriasis, asthma, allergic rhinitis, and sclerosis [31, 32]. Flavonoids produces antioxidative responses by acting free radical scavenger and chelating metal ions such as iron and copper, inhibiting the activity of enzyme like microsomal monooxygenase, glutathione- $S$-transferase, mitochondrial succinoxidase, and $\mathrm{NADH}$ oxidase because these enzymes are involved in generation of free radical species (ROS); flavonoids are also helping in protecting lipids from oxidative damage caused by free radicals [33]. In addition to antioxidative potentiality by free radical scavenging, flavonoids exhibit antimicrobial activity. Hyptis albida contain flavanoids with hydroxymethoxy flavones derivatives such as 5-hydroxy-7-4 dimethoxy flavones, 5-hydroxy-7-4-trimethoxy flavones, ermanin, nevadensin, and gardenin while in closely related Hyptis suaveolens, the flavonoid content ranges in between 10 and 13\% such as gallic acid, Ferulic acid, quercetin, chlorogenic acid, and rutin [34, 35]. Many flavonoids such as apigenin, catechin, naringenin, quercetin, and rutin are known for their hepatoprotective activity and flavonoids such as hesperidin, apigenin, and aluteolin have anti-inflammatory and analgesic activity [36].

\section{Terpenoids}

Terpenoids are the oxygenated derivatives of hydrocarbon secondary metabolites produced by the plants that 
constitute isoprene units having characteristic pleasant aroma that forms volatile aromatic compounds called essential oils [37]. The essential oils are basically monoterpenoids or sesquiterpenoids and their oxygenated derivatives. The monoterpenes are basically derived from precursor geranyl pyrophosphate while sesquiterpenes are derived from farnesyl pyrophosphate and constitute one of the largest groups of secondary metabolites produced in plants under stress conditions [38].

Iwu et al. (1999) by GC/MS analysis reported 32 terpenoid compounds including 16 monoterpenes and 13 sesquiterpenes from the essential oil content of $H$. suaveolens having antifungal and broad spectral antibacterial activity against both Gram-positive and Gram-negative bacteria [39]. The diterpenoids comprise structurally diverse compounds that may be acyclic or having 1-5 ring system synthesized by mevalonate pathway and they constitute the integrated potential components of large number of medicinal plants of present and future drugs [38]. Suaveolic

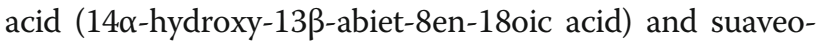
lol are two diterpenoid compound present abundantly in $H$. suaveolens, having high cytotoxic activity inhibiting growth of other plants adjacent to their clumps [40]. Plants specimens of $H$. suaveolens also contain three triterpene lactones and triterpenoid compounds like betulinic acid, ursolic acid, Beta sitosterol, oleanic acid, and acetyloleanic acid [34]. A new pharmacologically active pentacyclic triterpene Urs-12-en-3beta-29-oic acid have also been recorded from the H. suaveolens [41]. Diterpenoid endoperoxide, 13alpha-epi-dioxiabiet-8(14)-en-ol, present in petroleum ether extract of leaves of $H$. suaveolens have high antiplasmodic activity [42]. Ursolic acid (3$\beta$ hydroxy-urs-12-ene-28oic acid) is a natural pentacyclic triterpenoid $\left(\mathrm{C}_{30} \mathrm{H}_{48} \mathrm{O}_{3}\right)$ which is an important terpenoids reported in $H$. suaveolens and other members of family Lamiaceae. It is synthesized from dammarenyl cation by cyclization of squalene in plants cells having diverse therapeutic potential and pharmacological effect [43]. The natural ursolic acid that occur in many plant species under family Lamiaceae need more analytical evidence to develop it into future drug to treat chronic diseases like cancer, diabetes, and viral infections like AIDS, COVID-19, etc. [43, 44].

By GS analysis, Poonkodi et al. (2017) reported that the presence of several medicinally important terpenoids in essential oil of $H$. suaveolens which include sabinene, trans caryophyllene, E-spathulenol, Rimuene, 1,8-Cineole, Beta-Elemene, Eucaliptol, Bergamotol, Z-alphatrans, alpha-Selinene, Caryophyllene oxide, and alphahumulene [45].

\section{Alkaloids}

Alkaloids are secondary metabolites, having therapeutic properties. They have heterocyclic ring system with basic nitrogen atom. About 5500 alkaloids have been reported. Alkaloids have analgesic, antiplasmodic, and antibacterial properties that is why they are used for medicinal purpose [46]. The leaves of $H$. suaveolens are rich in alkaloids having medicinal implications [11, 12].

\section{Mineral elements}

Different parts of plant contain calcium $(\mathrm{Ca})$, potassium $(\mathrm{K})$, phosphorus $(\mathrm{P})$, nitrogen $(\mathrm{N})$, magnesium $(\mathrm{Mg})$, and Sodium $(\mathrm{Na})$ in different concentrations while the ground tissue of leaves roots and stems also contains crystals of calcium oxalate [47].

\section{Pharmacological effects of Hyptis suaveolens (L.) Poit. Antioxidative activity}

Oxidative stress is a metabolic impairment that results in an abrupt imbalance between generation and detoxification of reactive oxygen species (ROS) in human body.

Table 1 Bioactive phytochemicals in Hyptis suaveolens and their pharmacological effects

\begin{tabular}{|c|c|c|c|}
\hline $\begin{array}{l}\text { Phytochemical } \\
\text { constituents }\end{array}$ & Bioactive chemical compound & Pharmacological effect & References \\
\hline Phenolics & $\begin{array}{l}\text { Rosamarinic acid and Methyl } \\
\text { rosamarinate }\end{array}$ & $\begin{array}{l}\text { Antioxidative and anti-cancer property ( by acting as free radical scavenger, } \\
\text { hydrogen donar, metal chelators), protects human body from free radicals } \\
\text { and oxidative stress }\end{array}$ & $\begin{array}{l}{[18,22-27} \\
48,49]\end{array}$ \\
\hline \multirow[t]{2}{*}{ Flavonoids } & Apigenin, Naringenin, Querecetin, Rutin & Hepatoprotective activity & {$[24,35,36]$} \\
\hline & Hesperidin, Apigenin, Aluteolin & Anti-inflammatory and Anti-analgesic activity & {$[38,39]$} \\
\hline \multirow[t]{4}{*}{ Terpenoids } & $\begin{array}{l}\text { Limonene, Diterpenoids Suaveolol, } \\
\text { Suaveolic acid, } 5 \text { alpha-Androst-9(LL)- } \\
\text { En-12 }\end{array}$ & $\begin{array}{l}\text { Antifungal activity, Antibacterial (Inhibits growth of Gram +ve and Gram -ve } \\
\text { bacteria). }\end{array}$ & {$[39,50-52]$} \\
\hline & $\begin{array}{l}\text { Diterpenoids 13alpha-epi-dioxiabiet- } \\
\text { 8(14)-en-ol }\end{array}$ & Antiplasmodic activity & {$[42,53,54]$} \\
\hline & $\begin{array}{l}\text { Alpha-pinene, beta-pinene, terpinolene, } \\
\text { sabinene, beta cryophillene }\end{array}$ & Larvicidal activity against Aedes albopictus larvae. & {$[55]$} \\
\hline & Urosolic acid & Antiviral activity against AIDS virus and SARC-CoV2 Virus & $\begin{array}{l}{[5,9,44} \\
56-59]\end{array}$ \\
\hline
\end{tabular}


The ROS constitute of variable reactive species (singlet oxygen, hydrogen peroxide, nitric oxide radicals, hypochlorite radical, super oxide anion radical, lipid peroxides, hydroxyl radical, etc.), acting as free radical that reacts actively with cellular proteins, enzymes, nucleic acids, and lipids results in cellular damage and invites different categories of chronic diseases and syndromes. Human body is provided with complex antioxidant protection system (APS) to mitigate the consequences of oxidative stress by neutralizing the free radicals [47].

$H$. suaveolens, a depository of diverse polyphenolics and flavonoid compounds having effective antioxidant property due to strong radical scavenging ability as determined by several analytical methods including ABTS (2,2'azinobis-(3-ethylbenzothiazoline-6-sulfonic acid) and DPPH (2, 2-diphenyl-1-picrylhydrazyl) [60]. Majority of plant species belonging to aromatic family Lamiaceae are rich source of polyphenolic compounds having antioxidative activity [48, 61, 62]. Some plant species under family Lamiaceae also contain antioxidant like vitamin $\mathrm{C}$, vitamin $\mathrm{E}$, quercetin, isorhammetin, kaempferol, etc. [63].

Flavonoids, a group of polyphenolic compounds, occur abundantly in plants and have potential antioxidative activity due to prevalence of hydroxyl groups and possess strong ability to scavenge free radicals produced due to antioxidative stresses $[49,64]$.

The most characteristic of plant phenolics and polyphenols is the capacity to scavenge ROS derived from lipids, proteins, oligo-nucleotides, and low-density lipoproteins (LDLs). These species are harmful for human health, cause oxidative stress-related chronic, and age-related diseases, such as cardiovascular disease (atherosclerosis), neuro-degeneration, (Alzheimer's disease), carcinogenesis, and skin deterioration $[65,66]$. Plant polyphenolic compounds acts as antioxidant by chelating metal ions like $\mathrm{Fe}(\mathrm{I}), \mathrm{Fe}(\mathrm{III})$, $\mathrm{Cu}(\mathrm{I}), \mathrm{Cu}(\mathrm{II})$. These ions are responsible for conversion of peroxides $\left(\mathrm{H}_{2} \mathrm{O}_{2}\right)$ into aggressive hydroxyl anion by Haber Weiss reaction [67]. Poly-phenols block the action of superoxide generating enzymes like Xanthine oxidase and protein kinase $C$ [68]. The poly-phenols exhibit their antioxidant action by hydrogen-atom transfer (HAT) and singlet-electron transfer (SET) mechanism. In the former, the phenolic functional group transfer its hydrogen atom to free radicals while in latter the transfer of single electron results in formation of radical cation [68].

The antioxidative potentiality of natural polyphenolics compounds with variable hydroxyl group is due to their ability to scavenge diverse ROS species by suppressing their formation by modulating the enzyme activity involved in their production [69]. Polyphenols like flavonoids may have the ability to react with non-polar compounds in the membrane lipid preventing the lipid oxidation and thus protect the membrane structure and function from oxidation [70].

\section{Anti-cancerous activity}

Cancer is a group of diseases that results in uncontrolled division of cell producing mass of abnormal cells. It is caused by change (mutation) in genetic material leading to uncontrolled cell division. Modern medicine provides number of treatment methods such as chemotherapy, radiation therapy, immunotherapy, hormonal suppression, and monoclonal antibody therapy, but these treatments have serious side effects. The essential oil of $H$. suaveolens containing terpenoids like sabinene, $\beta$-caryophyllene, trans-caryophyllene, Spatulenol, $\beta$-spathulenol, $\beta$-elemene, $\gamma$-elemene, Rimuene, $\alpha$-humulene, Eucaliptol, 1-8-cineole, etc. as chief constituents show anti-cancer activity on MCF-7 cell line (cancer cell line of human breast) [45]. Ethanolic extract of $H$. suaveolens activates apoptosis process by inhibiting the activity of anti-apoptotic protein $\mathrm{Bcl} 2$ [71]. Ursolic acid can be employed as effective anticancer drug as it bears unique modulation effect on mitochondrial metabolism through multiple pathways promoting production of ROS that destabilize mitochondrial membrane potential, activating p53 pathway promoting apoptosis in cancerous cell [72]. The apoptosis as induced by ursolic acid involve caspase-dependent pathway of death of carcinoma cells [73]. Ursolic acid has the ability to target several signaling molecules involved in cellular transformation, cell proliferation, angiogenesis, and metastasis that results in cancer [50, 74-76]. Ursolic acid and related triterpenoids induces cell cycle arrest of cancerous cell lines by targeting carcinogenic enzyme through proteasome degradation [30]. Thus ursolic acid and its derivative can used as effective therapeutic agent against cancer.

\section{Antibacterial activity}

The flavonoids and phenolic compounds present in the essential oil of $H$. suaveolens exhibit strong antibacterial activity against pathogenic Gram-positive and Gramnegative bacteria such as Staphylococcus aureus, Salmonella typhi, Pseudomonas aeruginosa, Lactobacillus plantarum, Escherichia coli, Vibrio vulnificus, Enterococcus fecalis, and Streptococcus fecalis [26, 29]. But the antibacterial efficacy of phenolics and flavonoids present in essential oil of $H$. suaveolens is more pronounced in Gram-positive bacteria as compare to that of Gramnegative bacteria due to the presence of outer hydrophilic membrane in latter $[53,77,78]$.

\section{Antifungal activity}

In human beings, there are number of diseases caused by fungi such as dermatitis, ringworm, athelete's foot, aspergillosis, and mucormycosis [6, 7]. Essential oil from $H$. suaveolens shows strong antifungal activity against 
Aspergillus spp. (A. flavus, A. parasiticus, A. niger, A. ochraceus, A. fumigatus), Saccharomyces cerevisiae, Mucor sp., Fusarium moniliforme, etc. [54].

\section{Anti-hyperglycemic activity/anti-diabetic activity}

Hyperglycemia is the metabolic error in which glucose concentration increases in blood due to deficiency or insufficient production of pancreatic hormone insulin resulting in diabetes mellitus. Insulin deficiency in diabetic patient causes several abnormalities like accumulation of lipids (cholesterol and triglyceride). The methanolic extract obtained from the leaves of $H$. suaveolens exhibits anti-hyperglycemic activity in streptozotocin induced diabetic rats [55]. Ursolic acid a pentacyclic triterpenoid act as strong hypoglycemic agent enhances vesicular insulin transportation, secretion, and induces the uptake of insulin by the glucose transporter protein (GLUT4) located on plasma membrane by activating intracellular accumulation of calcium [79]. It also improves the insulin signaling in adipose tissue by enhancing the activity of beta cell function in streptoazotocin-induced diabetic mice [80].

\section{Anti-fertility activity}

Petroleum ether, alcohol, and aqueous extracts of $H$. suaveolens leaves show anti-fertility effect in pregnant rat. Studies showed that $100 \%$ anti-fertility activity shown by alcoholic extracts [81].

\section{Antiplasmodial activity/anti-malarial activity}

$H$. suaveolens is widely used in the treatment of malaria. It inhibits growth of both chloroquine-sensitive and chloroquine-resistant strains of Plasmodium falciparum under in vitro conditions. The chemical constituent responsible for this activity is dehydroabietinol that causes transformation of erythrocytes from discocytes to stomatocytes. Later, a diterpenoid 13alpha-epi-dioxiabiet-8(14)en-18-ol found from petroleum ether extract of $H$. suaveolens leaves also shows antiplasmodial activity [82, 83].

\section{Insect-repellent and Larvicidal activity}

Mosquito-borne diseases such as dengue fever, yellow fever, malaria, filariasis, viral encephalitis affects large human population. Their bite causes serious allergy, local skin reaction, and systemic reaction. Extract of $H$. suaveolens shows larvicidal activity against yellow fever mosquito Aedes aegypti (L), Aedes albopictus larvae. Larvicidal activity of this plant is due to compounds like alpha-pinene, beta-pinene, sabinene, terpinolene, betacaryophyllene, and 4-terpineol [84].

\section{Wound healing activity}

In wound healing process, a damaged tissue restored its normal state. It mainly depends on repairing ability of tissue. It occurs in three stages of inflammation, proliferation, and remodeling. In proliferative phase, angiogenesis (formation of new blood vessels from endothelial cells), collagen deposition, and wound contraction takes place. Alcohol, chloroform, ether, and petroleum extract of $H$. suaveolens showed wound healing activity by increasing hydroxyproline content, collagen deposition, dry weight of granulation tissue, and enhanced wound healing activity by increasing free radical scavenging action and by increasing the antioxidant enzymes in granuloma cells [85].

\section{Anti-inflammatory activity}

Anti-inflammatory activity shown by 2 diterpenes suaveolol, and methyl suaveolate against croton oil induced dermatitis of mouse ear. It induced dose-dependent edema inhibition [86]. The pentacyclic triterpenoid ursolic acid produces profound and effective antiinflammatory effects [51]. The anti-inflammatory effect of $H$. suaveolens by scavenging free radicals similar to standard anti-inflammatory drug Ibuprofen was reported by several authors $[52,87]$.

\section{Antiviral activity}

Viral diseases are emerging as major cause of threat to human life resulting in severe death of human population worldwide. The frequent emergence of drug-resistant viral strains and acute shortage of effective vaccines and therapeutic agents for management and prevention of the viral infections invite the need of development of plant-based antiviral drugs. The plant-based natural pentacyclic triterpenoids are promising group of compounds synthesized by squalene cyclization that have notable antiviral property [88]. The aqueous alcohol extract of $H$. suaveolens containing pentacyclic triterpenoids shows better inhibition ability against Chickunguniya virus of Asian strain $[89,90]$. The root extract contains antiviral compound ursolic acid that may act on HIV integrase, which prevent the replication of AIDS virus [9]. In Indian system of medicine, many plant members under family Lamiaceae are traditionally used for treatment of respiratory tract viral infection, cold, and fever [5]. Ursolic acid expresses its cytotoxicity and virucidal effect on rotaviruses by inhibiting the replication of viral particles and adversely effecting its particle maturation by targeting main viral proteins like VP6 and NSP2, that play crucial role in viral multiplication and pathogenicity thus by targeting early replication stages of viron, ursolic acid act as potent antiviral agent [91].

\section{Miscellaneous pharmacological effects}

The aqueous extract of the Hyptis suaveolens showed anti-ulcer activity against cysteamine hydrochlorideinduced gastric and duodental ulceration by increasing healing of duodental ulceration and prevents the 
duodental ulceration in rats [92]. Hexane extract showed gastroprotective activity. The extract of aerial part of the plant Hyptis suaveolens prevented pyrogallol induced suppression of (humoral immune response (HIR) and cell-mediated immune response (CMIR) and also prevented the lipid peroxidation (LPO). The ethanolic extract of $H$. suaveolens showed toxicity effect on larvae of yellow fever mosquito Aedes egypti. Hydro-distillate leaves of $H$. suaveolens have showed acaricidal potency in ruminants [93].

\section{Hyptis suaveolens as a source of potential therapeutic agent in COVID-19 treatment}

The present COVID-19 pandemic engulfing millions of human lives crossing the territorial barrier is caused by SARS-CoV2, a spherical or pleomorphic enveloped nucleocapsid particle of $\beta$-coronavirus category bearing crown of human ACE2 receptor-specific glycoproteinaceous projections called spike. Its genome consists of a large single-stranded positive sense RNA associated with nucleoprotein. It infects the upper respiratory tract of human beings causing acute respiratory distress syndrome and resultant pulmonary failure and fatality in human beings [94-96].

The glycoproteinaceous spike protein of SARS-CoV play crucial role in viral pathogenesis. It is made up of two subunits S1 head and S2 filament protruding as club-shaped projections from the viral envelope bearing specific superficial binding affinity with ACE2 receptors present on the surface of human respiratory tract $[56,57]$.

When the viral particles enter the host cell, the viral envelope gets dissolved due to the acidic $\mathrm{pH}$ of autophagosome and viral genomic positive sense RNA enters inside the host cell. Replication and transcription of viral genome occur at cytoplasmic membrane involving coordinated synthesis of continuous and discontinuous RNA. The 5' region of the SARS-CoV2 RNA that constitute the first open reading frame ORF $1 \mathrm{a} / \mathrm{b}$ synthesizes a large polypepeptide, polypeptide a/b $[58,59]$. These polypeptides are then processed by several virus-encoded proteases viz., chymotrypsin like-3CL $\mathrm{L}^{\text {pro }}$, main protease- $\mathrm{M}^{\text {pro }}-\mathrm{NSp} 5$ and papain like NSP3 proteases into 16 nonstructural proteins (nsps) that constitute the viral replicase-transcriptase system consisting of helicases, RNA-dependent RNA polymerase, and other nonstructural proteins that are packed in membrane vesicles and involved in viral multiplication and assembly [97]. The natural ursolic acid (3ß-3hydroxyl-urs-12-ene-28-oic acid, a pentacyclic triterpenoid) and its derivatives present in Hyptis suaveolens and other plants of family Lamiaceae act as potent antiviral agent against rotaviruses, $\mathrm{HIV}$, influenza, and hepatitis B and C viruses $[10,53,88,98,99]$.

Ursolic acid and pentacyclic triterpenoid act as strong protease inhibitor. The molecular docking simulation study based on integrated molecular modulation approach reveal that it act as potential inhibitor of main protease $\left(\mathrm{M}^{\text {pro }}\right)$ of SARS-CoV2 $[100,101]$ and chymotrypsin like $3 \mathrm{CL}^{\text {pro }}$ protein $[102,103]$ that are produced after the processing polypeptide $\mathrm{a} / \mathrm{b}$ and constitute the transcription replication machinery of SARS-CoV2. Thus the ursolic acid present in $H$. suaveolens can be used as therapeutic agent in targeting COVID-19 virus. The inhibitions of transcriptase-replicase enzyme adversely affecting the replication and assembly of corona viral particles and thus, ursolic acid and its derivative can emerge as potent therapeutic drug against COVID19 virus and other life-threatening RNA viruses [104]. $\beta$ sitosterol also exhibit antiviral property against COVID19 virus by targeting the receptor binding domain (RBD) of spike protein of virus interfering with the binding of viral spike protein with angiotensin-converting enzyme2 (ACE2) receptor on human host cell, blocking the invasion of SARS-CoV2 virus inside the host cell [105].

\section{Conclusion}

The present review tries to give broad and widespread assessment of medicinal value of underexplored, wild, and aromatic plant Hyptis suaveolens and future insight on its pharmacological expansion as effective therapeutic agent against metabolic and infective human disorders. The plant has well established antioxidative, anti-cancerous, anti-diabetic, anti-inflammatory, wound healing, cytotoxic, antiplasmodial, and antifungal properties due to the presence of diverse category of phytochemically active secondary metabolites having additive or synergistic pharmacological effects (Table 1). The presence of unique secondary metabolites like suaveolic acid, suaveolol, methyl suaveolate, $\beta$-sitosterol, ursolic acid, and phenolic compound like rosamarinic acid, methyl rosamarinate having potentiality to substitute the traditional drugs as therapeutic agent against the resistant and newly emerged bacterial and viral pathogens. Ursolic acid, pentacyclic triterpenoid compounds promote the apoptosis of cancerous cells by modulating diverse signaling molecules that induces cancer. It acts as protease inhibitor of main protease $\left(\mathrm{M}^{\mathrm{pro}}\right)$ and chymotrypsin like proteases $\left(3 \mathrm{CL}^{\mathrm{pro}}\right)$ of SARS$\mathrm{CoV} 2$ adversely affect its replication and particle assembly inside the host cells. Urosolic acid also has the ability to modify the integrase, a crucial enzyme needed for the establishment of HIV virus in human host cell. Thus secondary metabolites of $H$. suaveolens can be effectively exploited for the management of SARS-CoV2 responsible for present COVID-19 pandemic and HIV virus for which there is no effective vaccines have been developed till date. $H$. suaveolens, a widely grown weed plant, can be further explored and analyzed to develop potential, cost-effective drugs against ever mutating and resistant RNA viruses to save the humanity from deadly viral pathogens in future. 


\section{Acknowledgements}

Authors are thankful to Dr. A.S. Moses Principal and Dr. S. Chaturvedi, Head, Department of Botany, Ewing Christian College, Allahabad for providing necessary facilities and being source of encouragement in writing this review article.

\section{Plant authentication}

Plant specimen of Hyptis suaveolens (L.) Poit. growing in campus of Ewing Christian College was authenticated from the plant list of herbarium specimen housed in herbarium of BSI, Central circle, Allahabad (Contribution to the flora of Ewing Christian College (Allahabad) of Uttar Pradesh, Vaishya J K, and Mishra Sanjay Kumar, 2014, Asian J Adv Basic Sci, 2014 3(1): 20-27).

\section{Authors' contributions}

PM is the main contributor of the manuscript, SS helps in writing and editing, and SKM contributed in collecting data, editing, and submission/ correspondence of the above review article. All authors have read and approved the manuscript for submission to the editorial system of Future Journal of Pharmaceutical Sciences.

\section{Funding}

Not applicable.

\section{Availability of data and materials}

Not applicable.

\section{Declarations}

Ethics approval and consent to participate

Not applicable.

\section{Consent for publication}

Not applicable.

\section{Competing interests}

The authors declare that they have no competing interests.

Received: 9 November 2020 Accepted: 1 March 2021

Published online: 12 March 2021

\section{References}

1. Evans WC (2009) Basic metabolic pathways and the origin of secondary metabolites, Trease and Evans Pharmacognosy (16 ${ }^{\text {th }}$ Eds). Saunders Elsevier Publication, International Edition (Edinburg, London, New York, Philadelphia, St. Louis, Sydney). Pp. 148-167

2. Vanettan HD, Mansfield JW, Bailey JA, Farmer EE (1994) Two classes of plant antibiotics: Phytoalexins versus Phytoanticipins. Plant Cell 6(9):1191-1192

3. Cragg M, Newman DJ (2013) Natural products: a continuing source of novel drug leads. Biochem Biophys Acta 1830:3670-3695

4. Oliver B (1986) Medicinal plants in tropical West Africa. Cambridge University Press, London

5. Mabberley DJ (1990) The plant book. Cambridge University Press, London

6. Pandey DK, Tripathi N, Tripathi RD, Dixit SN (1982) Fungitoxic and phytotoxic properties of essential oils of Hyptis suaveolens. J. Plant Dis Prot 89:344-349

7. Singh G, Upadhyay RN, Rao GP (1992) Fungitoxic activity of volatile oil of Hyptis suaveolens. Fitoterpia 63:462-465

8. Asekum OT, Ekundayo O (2000) Essential oil constituents of Hyptis suaveolens (L.) Poit., (bush tea) leaves from Nigeria. J Essent Res 12:227-230

9. Chatterjee A, Pakarshi SC (1997) The treatise on Indian medicinal plants, Vol 5. PID, New Delhi

10. Tohme MJ, Gimanez MC, Perlata A, Colombo MI, Deluge LR (2019) Urosolic acid: a novel antiviral compound inhibiting rotavirus infection in vitro. Int J Antimicrob Agents 54(5):601-609. https://doi.org/10.1016/j.ijantimicag.2019. 07.015

11. Edeoga HO, Omosun G, Uche LC (2006) Chemical composition of Hyptis suaveolens and Ocimum gratissimum hybrids from Nigeria. Afr J Biotechnol 5(10):892-895

12. Ulhe SK, Narkhede SD (2013) Histological and phytochemical studies on aromatic plant, Hyptis suaveolens (L) of family Lamiaceae (MS) India. Sci Res Rep 3(1):44-48
13. Heywood VH, Bummilt Richard K, Ole S, Astan G (2008) Flowering plant families of the world. Firefly Book, Ontario ISBN-1-55407-206-4

14. The plant list (2013) The plant list of all plant species, version 1-1. Royal Botanic garden Kew, London http://www.theplantlist.org

15. Barbosa LCA, Martins FT, Teixeira RR, Polom MRM (2013) Chemical variability and biological activities of volatile oil from Hyptis suaveolens (L.) Poit. Agricultineae Conspectus Scientificus 78(1):10 https://www.dof.Gkd.au/-da ta/assetPat-file/0016/56401/IPA.Haehound.Pp120.pdf

16. Gadidasu KK, Murthy EN, Nataraj P, Srinivas K, Pa B, Teixeria da Siba JA, Raju VS, Sadanandan (2011) ISSR marker variants of Hyptis suaveolens. Med Aromat Plants Sci Biotechnol 5(2):166-168 https://www.gbif.org/species

17. Saha PR, Sinha S, Sinha RK (2017) Morphometric diversity of reproductive structures in Hyptis suaveolens $(\mathrm{L})$ Poit; an ethanomedical weed of Lamiaceae. Curr Botany 8:74-77

18. Jin D, Russel J, Mumker (2010) Plant Phenolics: extraction, analysis and their antioxidative and anticancer properties. Molecules 15(10):7313-7352

19. Harborne JB, Baxter H, Moss GP (1999) Phytochemical dictionary: a hand book of bioactive compounds from plants, 2nd edn. Taylor \&Francis, London

20. King A, Young G (1999) Characteristics and occurrence of Phenolics phytochemicals. J Am Diet Assoc 99:213-218. https://doi.org/10.1016/soo28223(99)00051-6

21. Tsao R (2010) Chemistry and biochemistry of dietry polyphenols. Nutrients: 1231-1246. https://doi.org/10.3390/nu2121231

22. Afanaas'ev IB, Dcrozhko Al, Bradskii AV, Kostyuk VA, Potapovitch Al (1989) Chelating and free radical scavenging mechanism of inhibitory action of rutin and quercetin in lipid peroxidation. Biochem Pharmacol 3:1763-1769

23. Stephane Q, Denis D, Celine DS, Laurent P (2011) Plant polyphenols; chemical properties, biological activies and synthesis. Angew Int Ed 50:586-621

24. Ghaffari H, Ghassam BJ, Prakash HS (2012) Hepatoprotective and cytoprotective properties of Hyptis suaveolens agains t oxidative stress induced damage. Asian Pac J Trop Med 5(11):868-874. https://doi.org/10.1 016/s1995-7645(12)60162x

25. Ghaffari H, Ghassam BJ, Nayaka SC, Ramchandra Kini K, Prakash HS (2014) Antioxidant and neuroprotectiveactivities of Hyptis suaveolens(L.) Poit. Against oxidative stress induced neurotoxicity. Cell Mol Neurobiol 34(3): 323-331. https://doi.org/10.1007/s10571-013-0016-7

26. Pham HNT, Sakaff JA, Vuong Q, Von Bowyer MC, Scarlett CJ (2018) Screening of phytochemical content, antioxidants, antimicrobial and cytotoxic activities of Catharanthus roseus (L.) G. Don. Stem extract and its fraction. Biocatal Agric Biotechnol 16:405-411. https://doi.org/10.1016/jbca b2018.09.05

27. Oscar SA, Antonio CN, Marina GV, Elsa RS, Gabriel VA (2020) Phytochemical screening, antioxidant activity and in vitro biological evaluation of leaf extract of Hyptis suaveolens (L.) from South Mexico. S Afr J Bot 128:62-66. https://doi.org/10.1016/Jsajb.2019.10.016

28. Ganiyu O (2008) Polyphenol extracts from Hyptis suaveolens leaves inhibit Fe2+- induced lipid peroxidation in brain. Int J Biomed Pharmaceutical Sci $1: 41-46$

29. Evans WC (2009) Flavone and related flavonoid glycosides, Trease and Evans Pharmacognosy (16 ${ }^{\text {th }}$ Eds). Saunders Elsevier Publication, International Edition (Edinburg, London, New York, Philadelphia, St. Louis, Sydney). Pp. 252-259

30. Neuhouser ML (2004) Flavonoids and cancer prevention: what is the evidence in human? Pharm Biol 42(supplement):36-45

31. Choy KW, Murugan D, Leong XF, Abas R, Alias A, Mustafa MR (2019) Flavonoids as natural antiinflammatory agents targeting nuclear factor KappB (NFkB) signaling in cardiovascular diseaes : a mini review. Front Pharmacol. https://doi.org/10.3389/fpharm.2019.01295

32. Serafini M, Peluso UI, Raguzzini A (2010) Flavonoids as anti-inflammatory agents. Proc Nutr Soc 69(3):273-278. https:/doi.org/10.1017/s00296651100012x

33. Wang T, Qing L, Bi K (2018) Bioactive flavonoids in medicinal plants; structure, activity and biological fate. Asian J Pharmaceut Sci 13(1):12-23. https://doi.org/10.1016/j.ajps,2017.08.004

34. Mirinda RP (1990) Triterpenoids anf flavonoids from Hypis albida. J Nat Prod 53(1):182-185

35. Asha D, Mathew L, Rishad KS (2015) Evaluation of HTPLC fingerprints of flavonoids and antioxiant activity of selected medicinal plants of Lamiaceae family. Int J Pharmacog Phytochem Res 7(2):240-245

36. Kumar S, Pandey AK (2013) Chemistry and biological activities of flavonoids: an overview. Sci World J. https://doi.org/10.1155/2013/162750 
37. Bruneton J (1999) Pharmacognosy, phytochemistry, medicinal plants, $2^{\text {nd }}$ edn. Lavoisier nd Publishing, Paris.

38. Evans WC (2009) Miscellaneous isoprenoids, Trease and Evans Pharmacognosy $\left(16^{\text {th }}\right.$ Eds). Saunders Elsevier Publication, International Edition (Edinburg, London, New York, Philadelphia, St. Louis, Sydney). Pp. 333-346

39. Iwu MM, Ezeugwu CO, Okunji CO, Dale SR, Tempesta MS (1990) Antimicrobial activity and terpenoids of the essential oil of Hyptis suaveolens. Int J Crude Drug Res 28:73-76

40. Islam M, Ohno O, Snenga K, Nogusschi HK (2014) Suaveolic acid : a potent phytotoxic substance of Hyptis suaveolens. https://doi.org/10.1155/2014/42 5942

41. Sharma PP, Roy Ram K, Anurag GD, Sharma KV (2013) Hyptis suaveolens (L) Poit; a phyto-pharmacological review. International Journal of Chemical and Pharmaceutical Sciences 4(1):1-11.

42. Nayak SP, Nayak S, Shety R, Das P (2010) Hyptis suaveolens Poit; a review on its phytochemical and pharmacological profile. Res J Pharmacog Phytochem 2(1):1-6

43. Seo DY, Lee SR, Jun-Won H, Mi-Hyun N, Rhee BD, Ko KS, Hyo-Bum K, Han J (2018) Ursolic acid in health and disease. Kor J Physiol Pharmacol. https:// doi.org/10.4196/kjpp.2018.22.3.235

44. Silva MGM, Vieira IGP, Mendes FNP, Albuquerque IL, dos Santos RN, Silva FO, Morais SM (2008) Variations of ursolic acid content in eight Ocimum species from north eastern Brazil. Molecules 13(10):2482-2487. https://doi. org/10.3390/molecules 13102482

45. Poonkodi K, Karthika J, Tamilselvi V, Anitha R, Vasanthamani S (2017) Chemical composition of essential oil of Hyptis suaveolens (L) Poit and its invitro anticancer activity. J Pharm Res 11(5):410-413

46. Roy A (2017) A review on the alkaloids an important therapeutic compound from plants. Int J Plant Biotechnol 3(2):1-9

47. Pizzino G, Irrera N, Cucinotta M, Pallio G, Mannino F, Arcoraci V, Squadrito F, Altavilla D, Bitto A (2017) Oxidative stress: harms and benefits for human health. Oxid Med Cell Longev. https://doi.org/10.1155/2017/8416763

48. Gulcin I, Elmastas M, Hassan A-EY (2007) Determination of antioxidant and radical scavenging activity of basil (Ocimum basilicum L. family Lamiacae) assayed by different methodologies. Phytother Res. 21(4):354-361

49. Rice Evans CA, Miller NJ, Bolwell PG, Broamley PM, Pridham JB (1995) The relative antioxidant activities of plant derived polyphenolic flavonoids. Free Radic Res 22(4):375-383

50. Yin R, Li T, Tian JX, Xi P, Liu RH (2018) Ursolic acid, a potential anticancer compound for breast cancer therapy. Crit Rev Food Sci Nutr 58(4):568-574. https://doi.org/10.1080/10408398.2016.1203755

51. Bariecevic D, Sosa S, Loggia RD, Tubaro A, Simonovoska B, Kransa A, Zupancic A (2001) Topical anti-inflammatory activity of Salvia officinalis L. leaves : the relevance of Ursolic acid. J Ethnopharmacol 75(2-3):125-132. https://doi.org/10.1016/S0378-8741(00)00396-2

52. Shenoy R, Shirwaekar A (2002) Anti-inflammatory and free radical scavenging studies of Hyptis suaveolens (Labiateae). Indian Drugs 39(11): 574-577

53. Jesus JA, Lago JH, Laurenti MD, Yamamoto ES, Passero LF (2015). Antimicrobial activity of oleanic and ursolic acid: An update, evidence based complementary and alternative medicine, https:/doi.org/10.1155/2015/620472

54. Moreira PCA, Lima E (2010) Chemical composition and antifungal activity of Hyptis suaveolens leaves essential oil against Aspergillus species. Braz J Microbiol 41:28-33

55. Mishra BS, Verma A, Mukerjee A, Vijay Kumar M (2011) Anti- hyperglycemic activity of leaves extract of Hyptis suaveolens $L$ Poit in Streptozotocin induced diabetic rats. Asian Pac J Trop Med. 4(9):689-693. https://doi.org/1 $0.1016 / s 1995-7645(11) 60175-2$

56. Tortorici MA, Veesler D (2019) Structural insights into coronavirus entry. Adv Virus Res 105:93-116

57. Xia S, Zhu Y, Liu M, Lan Q, Xu W, Wu Y, Ying T, Liu S, Shi Z (2020) Fusion mechanism of 2019- nCoV and fusion inhibitors targeting HR1 domain in spike protein. Cell Mol Immunol:1-3. https://doi.org/10.1038/s41423-020-03 $74-2.32$

58. Guo Y, Cao QD, Hong ZS, Tan YY, Chen SD, H J, Tan KS, De W, Yan Y (2019) The origin, transmission and clinical therapies on coronavirus disease 2019 (COVID-19) outbreak - an update on the status. Mil Med Res 7:11. https:// doi.org/10.1186/s40779-020-00240-0

59. De-Wilde AH, Snijder EJ, Kikkert M, Van Hemert MJ (2018) Host factors in coronavirus replication. Curr To Microbiol Immunol 419:1-42
60. Agarwal K, Varma R (2013) Antioxidant activity and phytochemical analysis of Hyptis suaveolens (L)Poit. J Adv Pharm Educ Res 3(4):541-549

61. Economou KD, Oreopoulou V, Thomopoulos (1991) Antioxidant activity of some plant extracts of the family Labiatae. J Am Oil Chemist Soc 68:109-113

62. Maksimovic Z, Stojanovic D, Sostaric I, Dajic Z, Ristic M (2008) Composition and radical- scavenging activity of Thymus glabrescens Willd.( Lamiacae) essential oil. J Sci Food Agric 88(11). https://doi.org/10.1002/jsfa.3311

63. Ghaffari H, Ghassam JB, Nayaka CS, Prakash SHK (2014) Antioxidant and neuroprotective activities of Hyptis suaveolens Poit, against oxidative stressinduced neurotoxicity. Cell Mol Neurobiol 34:323-331

64. Cook NC, Samman S (1996) Review: flavonoid chemistry, metabolism, cardioprotective effect and dietry sources. J Nutr Biochem 7(4):66-76

65. Durackova Z (2010) Some current insights into oxidative stress. Physiol Res 59(4):459-469

66. Kumar S, Pandey AK (2015) Free radicals: health implications and their mitigation by herbals. Brit J Med Med Res 7(6):438-457

67. Heim KE, Tagliaferro AR, Bobilya DJ (2002) Flavonoid antioxidants :chemistry , metabolism, and structure activity relationships. J Nutr Biochem 13(10): 572-584

68. Quideau S, Deffieux D, Douat-C C, Pouysegu L (2011) Plant polyphenols; chemical properties, biological activies and synthesis. Angew Int Ed 50:586-621

69. Hussain TR, Tan B, Yin Y, Blachier F, Tossou MCB, Raju (2016) Oxidative stress and inflammations: what polyphenols can Do for us? Oxid Med Cell Longev. https://doi.org/10.1155/2016/7432797

70. Oteiza PI, Erlejman AG, Verstraeten KCL, Fraga CG (2005) Flavonoids membrane interactions : a protective role of flavonoids at the membrane surface. Clin Dev Immunol 12(1):19-25

71. Gurunagarajan S, Pemaiah B (2011) Comparative studies on cytotoxic of Hyptis suaveolens Poit and Leonotis nepeatef r.Br against. EAC cell lines. J Pharm Res 4(4):1222-1224

72. Xue-min F, Lan SX (2019) Anticancer effect of ursolic acid via mitochondrial dependent pathway. Oncol Lett:4761-4767. https://doi.org/10.3892/01.201 9.10171

73. Lin CW, Chin HK, Lee SL, Chiu CF, Chung JG, Lin ZY, Wu CY, Liu YC, Hsio YT, Feng CH, Bai LY, Weng JR (2019) Ursolic acid induces apoptosis and autophagy in oral cancer cells. Environ Toxicol 34(9):983-991. https://doi. org/10.1002/tox.22769

74. Khwaja V, Oyedeji OO, Aderibigbe B (2020) Ursolic acid based derivatives as potential anticancer agent, an update. Int J Mol Sci 21(16):5920. https://doi. org/10.3390/ijms21165920

75. Iqbal J, Abbasi BA, Ahmad R, Mahmood T, Kanwal S, Ali B, Khalil AT, Shah SA, Alam MM, Badshah H (2018) Ursolic acid, a promising candidate in therapeutic of breast cancer, status and future implication. Biomed Pharmacother 108:752-756. https://doi.org/10.1016/J.biopha.2018.09.096

76. Lin J, Chin Y, Wei L, Hong Z, Sterra TJ, Peng J (2013) Ursolic acid inhibits colorectal cancer angiogenesis through suppression of multiple signaling pathway. Int J Oncol 43(5):1666-1674. https://doi.org/10.3892/ijo.2013.101

77. Bachheti RK, Rai I (2015) Chemical composition and antimicrobial activity of Hyptis suaveolens Poit. Seed oil from Uttarakhand state, India. Orient Pharm Exp Med 15:141-146

78. Nantitanon W, Chowwanapoonpohn S, Okongi S (2007) Antioxidant and antimicrobial activities of Hyptis suaveolens essential oil. Scientia Pharmaceutica (Scipharm) 75:35-46

79. Castro AJG, Silva FRMB (2015) The mechanism of action of Ursolic acid as insulin secretagogue and insuliniometric is mediated by cross talk between calcium and kinase to regulate glucose balance. Biochemica et Biophysica Acta (BBA) 1850(1):51-61. https://doi.org/10.1016/j.bba gen.2014.10.001

80. Jang SM, Yee ST, Choi J, Choi MS, Do GM, Jecon SM, Yeo J, Kim MJ, Ki S, Lee MK (2009) Ursolic acid enhances the cellular immune system and pancreatic beta cell function in streptozotcitin induced diabetic mice fed high fat diet. Int J Immunopharmacol 9:113-119

81. Sharma PP, Roy RK, Anurag GD, Sharma KV (2013) Hyptis suaveolens (L) Poit; a phyto-pharmacological review. Int J Chem Pharmaceut Sci 4(1):1-11

82. Dawet A, Anyanwu Dede MP, Uzolgwe (2012) In-vivo antimalarial activity of the ethanolic leaf extracts of Hyptis suaveolens Poit. On plasmodium berghei in mice. Int J Biol Chem Sci 6(1). https://doi.org/1 0.4314/ijbcs.v6i1.11

83. Chukwujekwu JC, Smith P, Coombes PH, Mulholland DA, Staden JV (2005) Antiplasmodial diterpenoid from the leaves of Hyptis suaveolens Ethnopharmacol 102(2):295-297. https://doi.org/10.1016/j.jep.2005.08.018 
84. Conti Barbara BG, Flamini G, Cioni LP, Raffaele P (2012) Larvicidal and repellent activity of Hyptis suaveolens (Lamiaceae) essential oil against the mosquito Aedes albopictus Skuse (Diptera;Culicidae). Parasitol Res 110:2013-2021

85. Shenoy C, Patil MB, Kumar R (2009) Wound healing activity of Hyptis suaveolens (L) Poit (Lamiaceae). Int J PharmTech Res 1:737-744

86. Grassi P, Urias TS, Reyes U, Tubaro A, Hofer O, Karin Z-E (2006) Antiinflammatory activity of two Diterpenes of Hyptis suaveolens from El Salvador, pp 165-170

87. Uritu C, Mihai TC (2018) Medicinal plants of the family Lamiacae in pain therapy; a review. Pain Res Manag 1:1-44

88. Khwaza V, Opeoluwa O, Oyedji Blessing AA (2018) Antiviral activity of oleanic acid and its analogues. Molecules 23(9):2300. https://doi.org/10.33 90/molecules.23.92300

89. Bhakat S, Saliman Mehmoud ES (2015) Chikungunya virus (CHIKV) inhibitors from natural sources: a medicinal chemistry perspective. J Nat Med 69:451462. https://doi.org/10.1007/s11418-015-0910-z

90. Kothaudan S, Swaminathan R (2014) Evaluation of inverts antiviral activity of Vitex negaudo (L) Hyptis suaveolens $(\mathrm{L})$ poit, Decapasis hameltonei Weght and Arn. To Chikungunya virus. Asian Pac J Trop Dis 4(1):511-515

91. Tohme MJ, Gimenez MC, Peralta A, Cololombo MI, Delgui LR (2019) Ursolic acid: a novel antiviral compound inhibiting rotavirus infection in vitro. Int J Antimicrob Agents 54(5):601-609. https://doi.org/10.1016/j.jjantimicag.2019. 07.015

92. John De Britto A, Sebastian SR, Sujin M (2012) Antibacterial activity of selected species of Lamiaceae against human pathogen. Indian J Nat Prod Resour 3(3):334-342

93. Ahmad S, Mahajan S, Sharma R (2013) Antibacterial activity of some medicinal plants of family Lamiaceae from Braj region. Glob J Med Plant Res 1(1):72-76

94. Su S, Wong G, Shi W, Liu J, Lai ACK, Zhou J, Liu W, Bi Y, Gao GF (2016) Epidemiology, genetic recombination, and pathogenesis of coronaviruses. Trends Microbiol 24:490-502. https://doi.org/10.1016/j.tim.2016.03.003

95. Forni D, Cagliani R, Clerici M, Sironi M (2017) Molecular evolution of human coronavirus genomes. Trends Microbiol 25:35-48

96. Zhong N, Zheng B, Li Y, Poon L, Xie Z, Chan K (2003) Epidemology and cause of severe acute respiratory syndrome (SARS) in Guangdong, People Republic of China, in February. Lancet 362(9393):1353-1358

97. Sawicki SG, Sawicki DL (2005) Coronavirus transcription : a perspective. Curr Top Microbiol Immunol 287:31-55

98. Kashiwada Y, Nagao T, Hashimoto A, Ikeshiro Y, Okabe H, Cosentino M, Lee KH (2000) Anti-AIDS agents: anti-HIV activity of 3-O- acyl Ursolic acid derivatives. J Nat Prod 63(12):1619-1622. https://doi.org/10.1021/np990633v

99. Chaniad P, Sudsai T, Septama AW, Chukaew A, Tewatrakul S (2019) Evaluation of ant-HIV-1 integrase and ant-inflammatory activities of compounds from Betula alnoides Buch ham. In: Advances in pharmacological and pharmaceutical sciences. https://doi.org/10.1155/2019.2573965

100. Kumar A, Choudhir G, Shukla SK, Sharma M, Tyagi P, Bhushan A, Rathore M (2020) Identification of phytochemical inhibitors against main protease of COVID-19, using molecular modeling approaches. J Biomol Struct Dyn. https://doi.org/10.1080/07391102.2020.1772112

101. Adem S, Eyupoglu V, Sarfroz I, Rasul A, Ali M (2020). Identification of potent COVID-19 main protease inhibitor ( $M^{\text {pro }}$ ) inhibitors from natural polyphenols : an in silico strategy unveils a hope against CORONA, preprint, https://doi. org/10.20944/preprints.202003.0333.v1

102. Zhou J, Huang J (2020) Current findings regarding natural components with potewntial anti -2019- n CoV activity. Front Cell Dev Biol. https://doi.org/1 0.3389/fcell.2020.00589

103. Sun N, Wong W, Guo J (2020). Prediction of Potential $3 \mathrm{CL}^{\text {pro }}$ targeting ant SARS_COv2 compound from Chinese Medicine, Preprints, doi: https://doi. org/10.2099/44preprints202003.0247.v1

104. Jee B, Kumar S, Yadav R, Singh Y, Kumar A, Sharma M (2018) Ursolic acid and Carvacrol may be potential inhibitor of dormancy protein ,small heat shock protein 16.3 of mycobacterium tuberculosis. J Biomol Struct Dyn 36(13):3434-3443. https://doi.org/10.1080/07391102.2017.1389305

105. Khan SL, Siddiqui FA (2020) Beta-Sitosterol : as immunostimulant, antioxidant and inhibitor of SARS-Cov2 spike glycoprotein. Arch Pharmacol Ther 2(1):12-16

\section{Publisher's Note}

Springer Nature remains neutral with regard to jurisdictional claims in published maps and institutional affiliations.

\section{Submit your manuscript to a SpringerOpen ${ }^{\circ}$ journal and benefit from:}

- Convenient online submission

- Rigorous peer review

- Open access: articles freely available online

- High visibility within the field

- Retaining the copyright to your article

Submit your next manuscript at $\boldsymbol{\nabla}$ springeropen.com 